\title{
KINERJA LEMBAGA ZAKAT DALAM PEMBERDAYAAN UMMAT (Studi pada Web Dompet Dhuafa, Lazis NU dan Lazis Muhammadiyah)
}

\author{
Muhammad Munadi \\ Muslimah Susilayati \\ Institut Agama Islam Negeri Surakarta \\ munadimabdiputra@gmail.com, muslimabsm@gmail.com
}

\begin{abstract}
Thispaper aims to describe the performance of zakat organizations for global empowerment (umma). The subjects of the study are three zakat organizations namely Dompet Dhuafa (DD), Lazis Nahdlatul Ulama (LAZISNU) and Lazis Muhammadiyah (LazisMU). Qualitative approach using content analysis is used to analyse the Data. The official websitesof those three zakat institution are used as primary sources. The results showed that the performance of Dompet Dhuafa is distinguished for its detail in the preparation of the vision, mission, goals, programs and organizational structures.Dompet Dhuafa develops the main program then makes it into specific program in details. There is relationship between vision, mission and objectives to reach both the local and global performance. LAZISMU is distinctive in optimizing the website. It can be foundthrough the use of four languages on the website: Bahasa Indonesia, Arabic, English, and France.LazisNU has outlined its program not only in the management of zakat, but also the empowerment.
\end{abstract}

Keywords: performance, zakat institutions, community empowerment

\begin{abstract}
Abstrak
Tujuan penelitian ini adalah untuk mengetabui kinerja lembaga zakat dalam pemberdayaan ummat pada lembaga amil zakat Dompet Dhuafa, LAZISNU Nahdlatul 'Ulama, dan LAZISMU Muhammadiyah. Penelitian ini menggunakan pendekatan kualitatif dengan teknik analisis data memakai konten analisis. Sumber primer berasal dari website resmi dari tiga lembaga zakat, yaitu: Dompet Dhuafa (DD), Lazis Nahdlatul Ulama (LAZISNU), dan Lazis Muhammadiyah (LAZISMU).Hasil penelitian menunjukkan bahwa kinerja Dompet Dhuafa unggul dilihat dari sisi penyusunan visi, misi, tujuan, program serta struktur organisasinya. Dompet Dhuafa sangat detil dalam mengembangkan program dari program utama menjadi program spesifik. Babkan dilihat dari program menunjukkan kesinkronan antara visi, misi dan tujuan yang menjadikan sasaran kerjanya berskala lokal sampai global. LAZISMU unggul dari sisi kinerja pemanfaatan website dilihat dalam sisi penggunaan empat bahasa dalam website, yaitu: Bahasa Indonesia, Bahasa Arab, Bahasa Inggris, dan Bahasa Francis. LAZISNU telah menjabarkan program kerja tidak hanya pada pengelolaan zakat tetapi sampai pada pemberdayaannya.
\end{abstract}

Kata kunci: kinerja, lembaga zakat, pemberdayaan ummat.

Permalink/DOI: http://dx.doi.org/10.18326/infs13.v10i2.289-308 


\section{Pendahuluan}

Begitu pentingnya zakat dan lembaga yang mengelolanya di negara berpenduduk muslim karena potensinya yang sangat besar bagi perkembagnan dan pertumbuhan ekonomi termasuk Indonesia. Hal ini dikarenakan potensi zakat infaq, shadaqah dan wakaf yang sangat besar di Indonesia. Ketua Umum Badan Amil Zakat Nasional (Baznas) Didin Hafidhuddin (Azra, 2012) menyatakan bahwa pada tahun 2011 realisasi dana filantropi Islam mencapai sekitar Rp 1,73 triliun. Jumlah ini tidak termasuk dana ZIS (zakat, infak, dan shadaqab) yang disalurkan langsung kepada mereka yang berhak menerimanya. Padahal, menurut beberapa estimasi, jika setiap dan seluruh Muslim Indonesia yang memiliki kelebihan rezeki dan harta mengeluarkan ZIS dan wakaf, potensi dana filantropi Islam Indonesia antara Rp 19 triliun hingga Rp 20 triliun per tahun.

Menurut UU No. 38 tahun 1999 tentang pengelolaan Zakat dan UU No. 17 tahun 2000 tentang zakat sebagai faktor komponen biaya pemotong pajak, maka diperlukan lembaga pengelola zakat yang memiliki kekuatan yuridis formal dan kredibel di mata masyarakat maupun pemerintah untuk menarik zakat sehingga bisa memotong pajak sebuah perusahaan/pribadi. Sudah banyak lembaga yang mengelola zakat dan yang sejenis di luar pemerintah seperti Dompet Dhu'afa Republika, Yayasan Solo Peduli, Pos Keadilan Peduli Ummat (PKPU), Rumah Zakat Indonesia (RZI) Ummul Quro', dan yang lainnya.

Lembaga zakat dalam mengelolanya diperlukan ukuran kinerja yang baik sehingga berimplikasi pada organisasi dan layanannya. Banyak faktor yang menentukan kinerja lembaga zakat. Hasil penelitian (Fadilah, 2013:30) menunjukkan bahwa lembaga zakat yang mengimplementasikan kontrol internal secara parsial dan berkelanjutan serta implementasi manajemen mutu terpadu secara signifikan mempengaruhi implementasi tatakelola yang baik secara langsung maupun tidak langsung. Hasil penelitian lain dari (Adnan, et al 2013) menunjukkan modal intelektual mempengaruhi kinerja lembaga zakat.Hasil penelitian (Noor, et al 2012:12) menunjukkan bahwa sistem pengukuran dan pengelolaan kinerja lembaga zakat harus bermakna dalam memonitor dan merawat kontrol proses 
penjaminan sebuah organisasi mencapai tujuan organisasi. Kinerja lembaga zakat juga tergantung pada sumber daya, proses, dan stakeholders. Tulisan hasil penelitian ini berupaya mengungkap kinerja lembaga zakat dalam pemberdayaan ummat.

\section{Kajian Teoritik}

Instrumen zakat, infaq, shadaqah, wakaf serta hibah sangat luas pemanfaatannya diantaranya pendapat berikut ini:

1. Pengembangan pendidikan dan budaya, meliputi: penyediaan buku gratis, pendanaan penelitian dan pengembanganyang relevan dengan pendidikan peningkatan program pendidikan, beasiswa, grant untuk sekolah, pemeliharaan dan pengembangan nilai-nilai budaya (Masyita, et al:2005).

2. Pendidikan, penelitian ilmiah dan perpustakaan, serta untuk memenuhi kebutuhan orang miskin (Kahf: 2003)

3. Pembangunan dan Pengadaan fasilitas pendidikan, serta biaya pendidikan formal dan non formal (Tamin, 2011: 42-47)

4. Kepentingan survival (food and nutrition), functioning (free from disease), progress (education and skills), and sustention (free from discrimination) needs of the poor (Hasan, 2006:3).

Keluasan cakupan peruntukan di atas bisa dijadikan rujukan bagi lembaga zakat untuk memperluas distribusinya. Dana ini bisa dialokasikan untuk mendukung implementasi karitatif maupun pengembangan sumber daya manusia.

\section{Lembaga Zakat Sebagai Lembaga Jasa}

Subianto (2002:18) memberikan pokok pemikirannya, bahwa karena zakat merupakan lembaga intermediasi uang, maka pengelolaannya harus seperti pengelolaan lembaga keuangan syariah (baitul maal). Baitul maal ini mengumpulkan dana pihak ketiga dari para muzakki untuk disalurkan kepihak ketiga lainnya yaitu mustahiq. Oleh karena itu, menurutnya sebagai baitul maal, diperlukan: a) Pengelola secara shidiq, amanah, tabliq dan fathonah (prudent); b) 
Jaringan dan infrastrutur (SOP dan teknologi); c) PR Marketing dan produk; d) Reward \& Punishment; dan e) Pengawasan.

Lovelock dan Wright (1999:14-15) menyatakan bahwa jasa memiliki 8P's, yang meliputi:Product Elements, Place, Cyberspace, and Time, Process, Productivity and Quality, People, Promotion and Education, Physical Evidence, serta Price and Other User Outlays.

Elemen pertama berkaitan dengan produk. Elemen ini mengharuskan manajer menyeleksi yang dihasilkan lembaga dengan mengacu pada manfaat yang diinginkan oleh pelanggan dan seberapa baik produk bersaing tampil. Elemen kedua berkaitan dengan tempat, waktu, dan cyberspace. Menyampaikan elemen produk kepada pelanggan melibatkan keputusan di kedua tempat dan waktu pengiriman dan dapat melibatkan saluran distribusi fisik atau elektronik (atau keduanya), tergantung pada sifat dari layananyang disediakan.

Layanan pesan dengan internet memungkinkan layanan informasi berbasisakan diserahkandi dunia mayauntuk pencarian melalui telepon atau komputer dimanapun dan kapanpun sesuai dengan kebutuhan pelanggan. Perusahaan dapat memberikan pelayanan langsung kepada pelanggan mereka atau melalui organisasi perantara seperti gerai ritel yang dimiliki oleh perusahaan lain, yang menerima fee atau persentase dari harga jual untuk melakukan tugas-tugas tertentu yang terkait dengan penjualan, layanan, dan pelanggan-kontak. Harapan pelanggan kecepatan dan kenyamanan menjadi faktor penentu penting dalam strategi pelayanan.

Elemen ketiga adalah proses. Proses ini menyangkut penyampaian produk kepada pelanggan membutuhkan desain dan pelaksanaan proses yang efektif. Sebuah proses menjelaskan metode dan urutan di mana sistem operasi layanan bekerja. Prosesyang didesain dengan buruk cenderung mengganggu pelanggan karena lambat, birokratis, dan tidak efektif pelayanan. Demikian pula, proses miskin membuat sulit bagi staf lini depan untuk melakukan pekerjaan mereka dengan baik, mengakibatkan rendahnya produktivitas, dan meningkatkan kemungkinan kegagalan layanan. 
Elemen keempat adalah produktivitas dan kualitas. Dua unsur ini harus dilihat sebagai dua sisi mata uang yang sama. Peningkatan produktivitas sangat penting untuk menjaga biaya yang harus ditanggung oleh pelanggan. Acuan yang dipakai oleh lembaga jasa adalah kualitas layanan harus seperti yang didefinisikan oleh pelanggan. Hal ini juga menjadi acuan bagi lembaga jasa untuk melakukan diferensiasi produk dan untuk membangun loyalitas pelanggan.

Elemen selanjutnya yaitu orang. Banyak layanan tergantung pada interaksi personal antara pelanggandan karyawan sebuah lembaga jasa. Sifat interaksi ini sangat mempengaruhi persepsi pelanggan atas kualitas layanan. Pelanggan sering menilai kualitas layanan yang mereka terima sebagian besar pada penilaian mereka tentang orang-orang yang menyediakan layanan tersebut. Perusahaan jasa yang sukses harus merekrut, melatih, dan memotivasi personil mereka orang-orang yang berada dalam kontak langsung dengan pelanggan.

Elemen berikutnya adalah Promosi dan Edukasi. Tidak ada program pemasaran dapat berhasil tanpa program komunikasi yang efektif. Komponen ini memainkan tiga peran penting: memberikan informasi dan saran yang dibutuhkan, membujuk target pelanggan tentang manfaat produk tertentu, dan mendorong mereka untuk mengambil tindakan pada waktu tertentu. Dalam pemasaran jasa, banyak komunikasi pendidikan di alam, terutama untuk pelanggan baru. Perusahaan mungkin perlu mengajarkan pelanggan ini tentang manfaat dari layanan, di mana dan kapan untuk mendapatkannya, dan bagaimana untuk berpartisipasi secara efektif dalam proses pelayanan. Komunikasi dapat disampaikan oleh individu, seperti tenaga marketing, atau melalui media seperti TV, radio, surat kabar, majalah, billboard, brosur, dan situs web.

Bukti fisik sebagai elemen berikutnya. Bukti fisik bisa meliputi bangunan, lansekap, kendaraan, bukti fisik interior: furnishing visual, peralatan, anggota staf, tanda-tanda, materi cetak, dan isyarat visual lainnya semua atau petunjuk berwujud lainnya yang memberikan buktinyata dari gaya layanan perusahaan dan kualitas. Lembaga jasa harus memberikan bukti pelayanan mengelola bukti 
fisik dengan hati-hati karena dapat berdampak besar pada kualitas, tayangan pelanggan.

Elemen berikutnya adalah Harga. Penentuan harga jasa yang akan dibeli oleh pelanggaran diukur berdasarkan pada pemerolehan manfaat dari produk jasa. (Andrews, et al2012:7) menyatakan bahwa pengaruh potensial pada kinerja organisasi di sektor publik dapat dikategorikan menjadi tiga set luas variabel: (1) lingkungan eksternal, (2) karakteristik organisasi internal dan (3) strategi manajerial.

\section{Analisis dan Pembahasan}

Penelitian ini menggunakan pendekatan kualitatif dengan teknik analisis data memakai konten analisis. Penelitian ini berupaya menemukan makna kinerja lembaga zakat pemberdayaan melalui website yang dimiliki. Sumber primer berasal dari website resmi dari tiga lembaga zakat, yaitu: Dompet Dhuafa (DD), Lazis Nahdlatul Ulama (LAZISNU), dan Lazis Muhammadiyah (LAZISMU). Ketiga lembaga ini dipilih karena dua alasan.

Alasan yang pertama karena memiliki website sebagaimana tertera pada tabel.1.

Tabel 1.

Alamat Web Resmi Tiga Lembaga Zakat

\begin{tabular}{lll}
\hline No & Nama Lembaga & Nama Web \\
\hline 1. & DD & http://www.dompetdhuafa.org/ \\
2. & LAZISNU & http://www.lazisnu.or.id/ \\
3. & LAZISMU & http://www.lazisnu.org/ \\
\hline
\end{tabular}

Alamat website ini menjadi pintu masuk dalam mendapatkan informasi berupa data-data dari konten yang ditampilkan. Data tersebut meliputi semua konten yang dimiliki dan diunggah oleh lembaga baik dari visi, misi, tujuan, struktur organisasinya sampai program kerjanya. 
Alasan yang kedua karena ketiga lembaga tersebut memiliki jaringan yang luas sebagaimana tercantum pada tabel 2 .

Tabel 2.

Jaringan Organisasi Lembaga Zakat

\begin{tabular}{|c|c|c|}
\hline No & Nama Lembaga & Jaringan Organisasi \\
\hline 1. & DD & 16 cabang dan 19 jejaring di seluruh dunia \\
\hline 2. & LAZISNU & $\begin{array}{l}18 \text { Pimpinan Wilayah dan } 24 \text { cabang } \mathrm{NU} \text { di } \\
\text { Indonesia }\end{array}$ \\
\hline 3. & LAZISMU & $\begin{array}{l}\text { Seluruh pimpinan wilayah dan cabang } \\
\text { Muhammadiyah di Indonesia }\end{array}$ \\
\hline
\end{tabular}

Tabel tersebut menunjukkan bahwa ketiga lembaga merupakan lembaga yang memiliki keluasan jaringan sehingga kegiatannya sangat luas minimal tingkat lokal dan nasional seperti yang ditunjukkan oleh LAZISNU dan LAZISMU. Sedangkan DD kegiatannya tidak terbatas pada tingkat lokal, nasional, regional, bahkan global. Lembaga inijuga memiliki cabang di luar negeri.

Keluasan jangkauan ini menjadikan lembaga memiliki web yang tidak hanya diakses oleh warga negara Indonesia saja akan tetapi lebih luas. Hal ini ditunjukkan dengan beberapa pilihan bahasa yang tersedia dalam website sebagaimana tercantum pada tabel 3 .

Tabel 3.

Pemakaian Bahasa dalam Web

\begin{tabular}{|c|c|c|}
\hline No & Nama Lembaga & Pilihan Bahasa (dalam Web) \\
\hline 1. & DD & Bahasa Indonesia dan Bahasa Inggris \\
\hline 2. & LAZISNU & Bahasa Indonesia \\
\hline 3. & LAZISMU & $\begin{array}{l}\text { Bahasa Indonesia, Bahasa Arab, Bahasa Inggris, } \\
\text { dan Bahasa Francis }\end{array}$ \\
\hline
\end{tabular}

Gambaran tersebut menunjukkan bahwa bahasa yang dipakai yang paling sedikit adalah LAZISNU karena hanya memakai Bahasa Indonesia, sementara yang paling progresif adalah LAZISMU yang 
memakai empat bahasa. Pemakaian bahasa asing dalam web bisa menjadikan seperti yang disampaikan Masha and (Karmela 2009:5) "effective ICT implementation enables extension of international relationships, helps adoption of quality international standards and strengthens ties with institutions abroad" "efektifitas implementasi ICT memungkinkan perluasan hubungan internasional, membantu adopsi standar kualitas internasional dan memperkuat hubungan dengan lembaga-lembaga luar negeri".

Pengembangan keluasan target pasar didukung dengan motto lembaga yang diperoleh dari konten masing-masing web yang disajikan pada tabel 4 .

\section{Tabel 4.}

\section{Motto Lembaga}

\begin{tabular}{lll}
\hline No & Nama Lembaga & Motto Organisasi \\
\hline 1. & DD & DD is Non Profit Organization for GLOBAL \\
2. & LAZISNU & Tidak tercantum dalam web \\
3. & LAZISMU & Tidak tercantum dalam web \\
\hline
\end{tabular}

Motto tersebut menunjukkan bahwa DD telah berupaya menyeiring sejalankan antara motto dengan target sasaran kegiatannya.

Hal ini masih didukung dengan visi lembaga yang tertulis pada tabel 5 .

\section{Tabel 5.}

\section{Visi Lembaga}

\begin{tabular}{lll}
\hline No Nama Lembaga & Visi \\
\hline & & Terwujudnya masyarakat dunia yang \\
& berdaya melalui pelayanan, pembelaan \\
dan pemberdayaan yang berbasis pada & sistem yang berkeadilan
\end{tabular}


Bertekad menjadi lembaga pengelola dana masyarakat (zakat, infak, 2. LAZISNU sedekah, CSR dll) yang didayagunakan secara amanah dan profesional untuk pemandirian umat

3. LAZISMU Menjadi Lembaga Zakat Terpercaya

Visi tersebut menunjukkan bahwa semua lembaga bercita-cita untuk menjadi lembaga terpercaya dalam mengelola dana ZIS atau yang sejenis. LazisNU dan LazisMU terkesan lebih dominan pada pengelolaan zakat, tetapi dilihat dari cita-cita program yang paling luas adalah DD karena tidak hanya pada pengelolaan saja namun pada tiga cakupan pelayanan, pembelaan dan pemberdayaan. Disamping itu DD memiliki sasaran programnya yang paling luas yaitu masyarakat dunia.

Semakin terlihat keluasan cakupannya ketika dilihat dari misi menunjukkan bahwa DD berusaha menjadi lembaga tingkat dunia yang mengurus filantropi sebagaimana dijelaskan pada tabel 6 .

Tabel 6.

Misi Lembaga Zakat

\begin{tabular}{|c|c|c|}
\hline No & $\begin{array}{c}\text { Nama } \\
\text { Lembaga }\end{array}$ & Misi \\
\hline & DD & $\begin{array}{l}\text { - Menjadi gerakan masyarakat dunia yang } \\
\text { mendorong perubahan tatanan dunia yang } \\
\text { harmonis } \\
\text { - Mendorong Sinergi dan Penguatan Jaringan } \\
\text { Kemanusiaan \& Pemberdayaan Masyarakat } \\
\text { Dunia } \\
\text { - Mengokohkan Peran Pelayanan, Pembelaan } \\
\text { \& Pemberdayaan } \\
\text { - Meningkatkan Kemandirian, Independensi } \\
\text { \& Akuntabilitas Lembaga dalam Pengelolaan } \\
\text { Sumber Daya Masyarakat Dunia } \\
\text { - Mentransformasikan Nilai-Nilai untuk } \\
\text { Mewujudkan Masyarakat Religius }\end{array}$ \\
\hline
\end{tabular}


- Mendorong tumbuhnya kesadaran masyarakat untuk mengeluarkan zakat, infaq dan sedekah dengan rutin dan tepat

- Mengumpulkan/menghimpun dan mendayagunakan dana zakat, infaq dan 2. LAZISNU sedekah secara profesional, transparan, tepat guna dan tepat sasaran

- Menyelenggarakan program pemberdayaan masyarakat guna mengatasi problem kemiskinan, pengangguran dan minimnya akses pendidikan yang layak

- Optimalisasi kualitas pengelolaan ZIS yang amanah, profesional dan transparan

3. LAZISMU - Optimalisasi pendayagunaan ZIS yang kreatif, inovatif dan produktif

- Optimalisasi pelayanan donatur

Misi ketiga lembaga di atas menunjukkan bahwa LazisNU dan LazisMU juga mengakomodasi pemberdayaan umat, tetapi misi lembaga DD selaras dengan visi yang menjangkau skala global yaitu mendorong perubahan tatanan dunia yang harmonis. Misi tersebut didukung dengan tujuan lembaga yang selaras pada tabel 9.

Tabel 9.

Tujuan Lembaga Zakat

\begin{tabular}{ll}
\hline No Nama Lembaga & Tujuan \\
\hline & Terwujudnya Organisasi DD dengan standar \\
& Organisasi Global \\
& Terwujudnya Jaringan \& Aliansi Strategis Dunia \\
& yang kuat \\
& Terwujudnya perubahan sosial melalui advokasi \\
& multi-stakeholder \& program untuk terciptanya \\
& kesejahteraan Masyarakat Dunia \\
& Menjadi lembaga filantropi Islam internasional \\
& yg transparan dan akuntabel \\
& Membangun sinergi dan jaringan global \\
& Terwujudnya Jaringan \& Aliansi Strategis Dunia \\
& yang kuat \\
&
\end{tabular}


Menjadi lembaga rujukan di tingkat global dalam program kemanusiaan dan pemberdayaan

Meningkatkan kualitas dan akses masyarakat terhadap program pelayanan, pembelaan dan pemberdayaan Mengokohkan peran advokasi untuk mewujudkan sistem yg berkeadilan Menguatkan volunteerism dan kewirausahaan sosial dimasyarakat

Menumbuhkan kepemilikan asset dimasyarakat melalui pengembangan industri kerakyataan Terwujudnya tata kelola organisasi berstandar internasional

Terwujudnya kemandirian organisasi melalui intensifikasi, ekstensifikasi \& diversifikasi sumber daya organisasi Terpeliharanya independensi lembaga dari intervensi pihak lain dan conflict of interest dalam pengelolaan lembaga

Menumbuh kembangkan semangat inklusifitas dan altruisme

Membangun Komunitas berbasis masjid Melahirkan kader dakwah

Meningkatkan kesadaran masyarakat untuk menerapkan Nilai Dasar Islam dalam kehidupan sehari-hari

2. LAZISNU Tidak tercantum di web

3. LAZISMU Tidak tercantum di web

Tujuan DD sangat menekankan pada perkembangan tuntutan global dari pemenuhan oraganisasi dengan standar Organisasi Global dengan mengembangkan jaringan dana liansi strategis dunia yang kuat sehingga terwujud perubahan sosial dan kesejahteraan masyarakat dunia.

Visi, misi, dan tujuan lembaga tidak akan bisa terimplementasikan dengan baik tanpa didukung oleh struktur organisasi yang mendadai. Ketiga lembaga zakat ini memiliki struktur organisasi sebagai tertera pada tabel 10. 
Tabel 10.

Struktur Umum Kelembagaan Zakat

\begin{tabular}{ll}
\hline No Nama Lembaga & Komposisi Struktur Organisasi \\
\hline & Dewan Pengurus \\
& Presiden Direktur \\
& Direktur Eksekutif \\
& Direktur Program \\
& Direktur Komunikasi \& \\
& Pengembangan Sumberdaya \\
& Direktur Pengembangan Sosial \\
& Direktur Keuangan \& Umum \\
& Dewan Pembina \\
& Ketua Dewan Pembina \\
& Anggota Dewan Pembina \\
& Anggota Dewan Pembina \\
& Dewan Pengawas \\
& Ketua Dewan Pengawas \\
& Anggota \\
& Dewan Penasehat Syariah \\
DD & Ketua Dewan Penasehat Syariah \\
& Anggota \\
& Ketua \\
& Wakil Ketua \\
& Sekretaris \\
Wakil Sekretaris & Bendahara \\
Wakil Bendahara \\
Manajemen Eksekutif \\
Direktur \\
Program Director \\
\\
\end{tabular}


Tabel 10.

Struktur Umum Kelembagaan Zakat(Lanjutan)

\begin{tabular}{lll}
\hline No Nama Lembaga & Komposisi Struktur Organisasi \\
\hline \multirow{2}{*}{ 2. LAZISNU } & Fundraising Manager \\
& Program Officer \\
& Fundraising \\
& Staff Finance \\
& Wali Amanah \\
& Dewan Syariah \\
& Dewan Pengawas \\
& Badan Pengurus \\
& Badan Ekskutif \\
& Direktur Utama \\
& Marketing Director \\
& Prodev Director \\
& Corporate Secretary \\
& Finance Director \\
\hline
\end{tabular}

Tabel tersebut menunjukkan bahwa struktur organisasi yang mirip terjadi pada DD dengan LAZISMU, yaitu pada sisi Dewan syariah, Dewan pengawas, dan dewan pengurus. Hal ini berbeda dengan yang terjadi pada LAZISNU. Namun demikian struktur organisasi tersebut menunjukkan bahwa organisasi zakat harus dikelola secara profesional dan dipegang oleh orang yang ahli dalam bidangnya yang memiliki setidaknya pengetahuan, kecerdasaran serta kecakapan interpersonal. Pengelolaan semacam itu searah dengan pendapat (Danyi 2009:177) bahwa "People employed in a professional service organization can be defined and measured according to three basic factors: knowledge, intelligence, and interpersonal skills".

Organisasi di atas juga sudah sesuai dengan ketentuan perundangan yang berlaku yaitu UU No. 38 tahun 1999 Tentang Pengelolaan Zakat pasal 8 pembentukan Badan/Lembaga Amil Zakat memiliki tiga unsur yaitu: unsur pertimbangan, unsur pengawasan, dan unsur pelaksana. Sisi unsur pelaksana menurut UU tersebut pada penjelasan pasal 6 ayat 5 dinyatakan unsur pelaksana bisa terdiri atas unit administrasi, unit pengumpul, unit pendistribusian dan unit lain sesuai dengan kebutuhan. 
Profesionalitas organisasi dapat ditunjukkan melalui programprogram yang mengarah pada pengembangan sumber daya manusia. Ketiga organisasi zakat memiliki program sebagaimana tercantum pada tabel 11.

\section{Tabel 11.}

\section{Program Utama Lembaga Zakat}

\begin{tabular}{lll}
\hline No Nama Lembaga & Program Utama \\
\hline 1. DD & $\begin{array}{l}\text { Heath, Education, Economy, dan Social } \\
\text { Develpmnet }\end{array}$ \\
& NU Smart \\
& NU Skill \\
& NU Preneur \\
& NU Care \\
2. LAZISNU & Education Development: save our school, \\
& Trens Sains, GOTA \\
& Economic Emprowerment \\
& Agriculture Empowerment \\
& Social Service \\
& Kurban Pak Kumis \\
3. & LAZISMU & \\
&
\end{tabular}

Program utama ketiga lembaga zakat menurut tabel 11 di atas, meliputi semua dimensi sumber daya manusia bersifat karitatif maupun non karitatif. Penjabarannya dapat dilihat di tabel 12 berikut. 


\section{Tabel 12.}

Jabaran Program Lembaga Zakat

\begin{tabular}{ll}
\hline No Nama Lembaga & Penjabaran Program Utama \\
\hline HEALTH \\
Layanan Kesehatan Cuma-cuma \\
RS. Rumah Sehat Terpadu \\
EDUCATION \\
SMART Ekselensia Indonesia \\
FIS Filial \\
Sekolah Guru Indonesia \\
Beastudi Indonesia \\
Makmal Pendidikan \\
Institut Kemandirian \\
Kampus Umar Usman \\
ECONOMY \\
Pertanian Sehat Indonesia \\
Kampoeng Ternak Nusantara \\
Tebar Hewan Kurban \\
\hline
\end{tabular}

Tabel 12.

Jabaran Program Lembaga Zakat(lanjutan)

\begin{tabular}{ll}
\hline No Nama Lembaga & Penjabaran Program Utama \\
\hline & Karya Masyarakat Mandiri \\
& Tabung Wakaf Indonesia \\
& IMZ \\
& Dompet Dhuafa Travel \\
& SOCIAL DEVELOPMENT \\
& Lembaga Pelayan Masyarakat \\
& Migrant Institute \\
& Disaster Management Centre \\
& Semesta Hijau
\end{tabular}


2. LAZISNU

3. LAZISMU
NU Smart: Bantuan pendidikan bagi keluarga tidak mampu

NU Skill:Pembekalan ilmu-ilmu terapan yang diperuntukkan bagi anak-anak putus sekolah atau yang tidak melanjutkan ke pendidikan lebih tinggi

NUPreneur: Permodalan dan pendampingan usaha bagi pedagang kaki lima dan usaha rumahan

NU Care: Program bantuan langsung (Immediate aid) dan tanggap bencana

Tidak tercantum dalam web

Dompet Dhuafa sangat detail dalam mengembangkan program dari program utama menjadi program spesifik. Bahkan dilihat dari program di atas menunjukkan kesinkronan antara visi, misi dan tujuan yang menjadikan sasaran kerjanya berskala lokal sampai global. Hal tersebut terlihat pada program migrant institute dan semesta hijau. Dua lembaga lain juga singkron tetapi masih menjadikan sasaran programnya masih bersifat lokal sampai nasional sesuai dengan visi, misi dan tujuan organisasinya. Dompet Dhuafa yang memiliki target yang luas ini bisa menjadikan organisasinya seperti pendapat dari Garbarinoand Johnson serta serta Rothschild yang dikutip Adrian Sargeant and Walter Wymer (2007:31) bahwa:

"Funders, however, are not the direct consumers of an Non Profit Organization's services, nor do they normally have direct experience or involvement in service delivery. found that trust is more important in generating long-term loyalty than the benefits received in the exchange itself".

Kepercayaan lebih penting dalam menghasilkan loyalitas jangka panjang dibandingkan dengan manfaat yang diterimater jadi antara lembaga jasa dengan para pelanggarannya. Roshaiza Binti Taha (2015:9) In Malaysia Zakat has been seen as a tool to assist Muslim for better life.Marghoob A. Quraishi. (1999:2) From a microeconomic perspective, zakat is a mechanism for self-help. 
Azyumardi Azra yang dikutip Ahmad Najib Burhani (2013) pernah menyatakan bahwa jika dana Ziswah itu bisa dimanfaatkan dengan baik, maka LSM (Lembaga Swadaya Masyarakat) di Indonesia yang selama ini sangat bergantung pada pemberian dana dari luar negeri akan bisa bersikap lebih independen dengan cara melepaskan ketergantungannya pada lembaga-lembaga donor asing.

\section{Kesimpulan}

Kinerja lembaga zakat dalam pemberdayaan ummat dapat diketahui dari informasi pada konten web DD, LazisNU dan LAZISMU. Dilihat dari sisi penyusunan visi, misi, tujuan, program serta struktur organisasinya yang diupload melalui website masing-masing lembaga, Dompet Dhuafa lebih unggul karena sangat detil dalam mengembangkan program dari program utama menjadi program spesifik. Bahkan dilihat dari program menunjukkan kesinkronan antara visi, misi dan tujuan yang menjadikan sasaran kerjanya berskala lokal sampai global.

Dilihat dari sisi kinerja pemanfaatan website LAZISMU lebih unggul karenamenggunakan empat bahasa dalam website, yaitu: Bahasa Indonesia, Bahasa Arab, Bahasa Inggris, dan Bahasa Francis. LAZISNU telah menjabarkan program kerja tidak hanya pada pengelolaan zakat tetapi sampai pada pemberdayaannya. 


\section{Daftar Pustaka}

Adnan, Nur Syuhada, Amrizah Kamaluddi and Nawal Kasim. 2013. Intellectual Capital in Religious Organisations: Malaysian Zakat Institutions PerspectiveMiddle-East Journal of Scientific Research 16 (3): 368-377

Andrews, Rhys, George A. Boyne, Jennifer Law, and Richard M. Walker. 2012. Strategic Management and Public Service Performance. New York:Palgrave Macmillan

Azra, Azyumardi. 2012. Filantropi untuk Kohesi Sosial. http: // nasional. kompas.com/read/2012/08/18/1654224/Filantropi. untuk. Kohesi.Sosial

British Journal of Economics, Finance and Management Sciences 12 August 2012, Vol. 5 (1).

Burhani, Ahmad Najib. 2013. Zakat untuk Civil Society.

Danyi, Saiki. 2009. Services Marketing. Jaipur: Oxford Book Company.

Fadilah, Sri. 2013. The Influence Of Good Governance Implementation To Organization Performance: Analysis Of Factors Affecting(Study On Intitution Amil Zakat Indonesia). The internasional Journal of Social Sciences. 30 ${ }^{\text {th }}$ January 2013. Vol.7 No. 1 www.TIJOSS.com

Hasan, Sami. 2006. Muslim Philanthropy and Social Security: Prospects, Practices, and Pitfalls. A paper presented at the $6^{\text {th }}$ ISTR Biennial Conference held in Bangkok, 9-12 July 2006.

Iniguez, Alma Arcelia Ramírez. 2011. Conditions for the internationalisation of higher education: between inclusion and exclusion in a globalised world.

Kahf, Monzer. 2003. The Role of Waqf in Improving The Ummah Welfare. Presented to The International on "Waqf as a Private Legal Body" organized by the Islamic University of north 
Sumatra, Medan, Indoneasia Jan. 6-7, 2003.

Kahf, Monzer. 1999. The Performance of The Institution of Zakah Theory and Practice. Paper prepared for the International conference on Islamic Economics Toward the $21^{\text {st }}$ Century, Kuala Lumpur, April 26-30, 1999.

Kaslam, Shawal. 2007. Governing Zakat as a Social Institution: The Malaysian Perspective. Kertas kerja Persidangan Zakat Asia Tenggara, Padang Sumatera, November 2007.

Latif, Hilman. 2010. Menggali Potensi Filantrofi Lewat LAZISMU.

Masha, Magzan and Karmela, Aleksic-Maslac. 2009. ICT as an effective tool for internationalization of higher education. Paper presented at the World Multiconference on Systemics, Cybernetics and Informatics (13th, Orlando, FL, Jul 10-13, 2009).

Masyita, Dian, Muhammad Tasrifm dan Abdi Suryadinata Telaga. 2005.A Dynamic Model for Cash Waqf Management as One of The Alternative Instruments for the Poverty Alleviation in Indonesia.

Mawardi. 2005. Strategi Efektifitas Peran Lembaga Zakat Di Indonesia Hukum Islam. Vol. IV No. 2 Desember 2005

Noor, Abd Halim Mohd, Mohamed Saladin Abdul Rasool, Rozman Md. Yusof Siti Mariam Ali, and Rashidah Abdul Rahman. 2014. Efficiency of Islamic Institutions: Empirical Evidence of Zakat Organizations' Performance in Malaysia. Journal of Economics, Business and Management, Vol. 3, No. 2, February 2015

Noor, Abd. Halim Mohd, Mohamed Saladin Abdul Rasool, Rashidah Abdul Rahman, Rozman Md. Yusof, and Siti Mariam Ali. 2012. Assessing Performance of Nonprofit Organization: A Framework for Zakat Institutions

Quraishi, Marghoob A. 1999. The Institution of Zakat and Its Economic Impact on Society. Proceedings of the Second Harvard University Forum on Islamic Finance: Islamic Finance into the 21st Century. Cambridge, Massachusetts. Center for Middle Eastern Studies, Harvard University. 1999. pp.77-81 
Roshaiza Binti Taha. 2015. Zakat: Optimum Economic Aids. Waikato Islamic Studies Conference Programme and Abstracts. 11-12 November 2015S Block, Level 1The University of WaikatoHamilton, New Zealand.

Saidi, Zaim. 2003. Sumbangan sosial perusahaan.Jakarta: PIRAC.

Sargeant, Adrian \& Wymer, Walter. (editor). 2007.The Routledge Companion to Nonprofit Marketing. New York: Routledge.

Subianto, Achmad. 2002. Manajemen Zakat Di Indonesia. Makalah dalam Work Shop Zakat Infak dan Shadaqah. Yogyakarta: Pusat Studi Islam - UII

Tamin, Imron Hadi. 2011. Peran Filantropi Dalam Pengentasan Kemiskinan Di Dalam Komunitas Lokal Jurnal Sosiologi Islam, Vol. 1, No.1, April 2011.

UU No. 38 tahun 1999 Tentang Pengelolaan Zakat. 